\title{
Manuka Honey-induced Cytotoxicity against MCF7 Breast Cancer Cells is Correlated to Total Phenol Content and Antioxidant Power
}

\author{
I. Portokalakis ${ }^{1}$, H. I. Mohd Yusof ${ }^{1}$, D. F. Ghanotakis ${ }^{2}$, P. Singh Nigam ${ }^{1}$ \\ and R. Owusu-Apenten ${ }^{1^{*}}$ \\ ${ }^{1}$ Faculty of Life and Health Sciences, School of Biomedical Sciences, Ulster University, \\ Cromore Road, Coleraine, BT52 1SA, UK. \\ ${ }^{2}$ Department of Chemistry, University of Crete, Voutes-Heraklion, Crete, 70013, Greece.
}

\section{Authors' contributions}

This work was carried out in collaboration between all authors. Authors ROA, PSN and DFG designed the study, wrote the protocols and performed training and supervision. Authors IP and HIMY performed all experimental work and managed the data analysis. Author IP wrote the first draft of the manuscript. All authors read and approved the final manuscript.

Article Information

DOI: 10.9734/JABB/2016/27899 Editor(s):

(1) James W. Lee, Department of Chemistry and Biochemistry, Old Dominion University, USA.

Reviewers:

(1) Anonymous, Universiti Teknologi MARA (UiTM), Malaysia.

(2) Hao Wang, Northeastern University, Shenyang, Liaoning 110819, China (3) Małgorzata Przygodzla, Sensory Laboratory, Institute of Animal Reproduction and Food Research of Polish Academy of Sciences in Olsztyn, Poland.

(4) Evangelos Marinos, University of Athens, Athens, Greece. (5) Mehlika Benli, Ankara University, Turkey. Complete Peer review History: http://www.sciencedomain.org/review-history/15561

\section{ABSTRACT}

Aims: To investigate the relations between total polyphenols content, antioxidant power and Manuka honey cytotoxicity towards MCF-7 cells.

Study Design: In vitro study.

Place and Duration of Study: Department of Chemistry, University of Crete in partnership with the School of Biomedical Sciences, Ulster University, 09/ 2014 - 09/ 2015.

Methodology: Manuka honey (UMF 5+,10+, 15+ and 18+) were examined for total phenols content using the Folin-Ciocalteu method with results expressed as mg gallic acid equivalents per $\mathrm{kg}$ honey (mg GAE/kg). Antioxidant power was evaluated using the Ferric Reducing Antioxidant Power "FRAP" method and expressed as $\mathrm{mg}$ GAE/kg. Honey cytotoxicity was examined with MCF-7 breast 
cancer cells cultured with RPMI 1640 supplemented with charcoals stripped serum and viability was monitored using the MTT assay.

Results: The total phenols content for Manuka honey ranged from $1367 \pm 152 \mathrm{mg} \mathrm{GAE} / \mathrm{kg}$ for UMF 5+ honey to $2358 \pm 79 \mathrm{mg}$ GAE/ kg for UMF 18+ honey. The antioxidant power for Manuka honey ranged from $170 \pm 22 \mathrm{mg} \mathrm{GAE} / \mathrm{kg}$ for UMF 5+ honey rising to $266 \pm 21 \mathrm{mg} \mathrm{GAE} / \mathrm{kg}$ for UMF 18+ honey. Manuka honey showed dose-dependent cytotoxicity towards MCF-7 cells after 24 hrs. treatment. The concentration of honey which produces $50 \%$ inhibitory activity $\left(\mathrm{IC}_{50}\right)$ ranged from $4.7 \%(\mathrm{w} / \mathrm{v})$ for UMF $5+$ honey to $2.2 \%(\mathrm{w} / \mathrm{v})$ for UMF $18+$ honey. The cytotoxicity of Manuka honey was highly correlated with, values for the total phenols content $\left(R^{2}=0.99\right)$ and antioxidant power $\left(R^{2}=0.95\right)$ of Manuka.

Conclusion: Manuka honey is cytotoxic to MCF-7 breast cancer cells in vitro and the effects are correlated with the total phenols content and antioxidant power.

Keywords: Manuka honey; MCF-7; breast cancer; antioxidant power; anticancer action; polyphenols.

\section{INTRODUCTION}

There is renewed interest in honey owing to its antioxidant and anti-inflammatory potential, emerging role as a functional food [1], possible use against drug resistant bacteria [2], and applications for cancer therapy [3]. Honey polyphenols produce antioxidant and antiinflammatory action by scavenging reactive nitrogen and oxygen species [4]. Polyphenols also down-regulate cycloxygenase-2 and inducible nitric oxide synthase [5] and may hinder cell mutation by inhibiting cytochrome P450 family and inducing phase II detoxification enzymes [6]. The mechanisms proposed for honey anticancer activity include, induction of cell apoptosis via caspase-8/9 dependent pathways, cell cycle blockage at the $G_{0} / G_{1}$ phase, regulation of Tumor-Necrosis Factor (TNF) family proteins or anti-estrogenic activity $[3,4]$.

Breast cancer is the most important genderspecific cancer in women with 1.7 million cases in 2012 [7]. Current research into the effect of honey on breast cancer cells is limited. Three studies focused on Tualang honey $[8,9,10]$, one considered Manuka honey [11] whilst two studies examined the effect of honey extracts $[12,13]$. Thyme and pine fir honey extracts showed no inhibition of MCF-7, but instead showed antiestrogen activity $[12,13]$. Tualang honey was cytotoxic to the MCF-7 and MDA-MB-31 cells and protective with normal breast epithelial cells. Tualang honey and tamoxifen combinations produced synergistic interactions $[8,9,10]$. There was significant cytotoxicity when MCF-7 cells were exposed to honey with "Unique Manuka Factor" (UMF) rating $10+$ but no other UMF ratings were examined [11].

Manuka honey exhibits non-peroxide antibacterial activity attributed to polyphenols and methylglyoxal. Indeed, levels of polyphenols, methylglyoxal or methyl-syringate [14] are considered quality markers for Manuka honey, indicative of geographic origin and harvesting season [15]. Polyphenols identified in Manuka honey include phenolic acids, gallic acid $[1,3]$ methyl-syringate or leptosperin [14] and phenylacetic acid. The main flavonoids in Manuka were found to be chrysin, galangin, pinocembrin and pinobanskin [16]. We reported a strong correlation between total phenols content and ferric reducing antioxidant power (FRAP) and honey UMF rating $5+, 10+, 15+$ and $18+$ [17]. Manuka honey also inhibited MDA-DB-231 cells (unpublished results). However, the possible association of between total phenols content, antioxidant power and Manuka honey cytotoxicity has not been explored. The aims of this study were, to investigate whether Manuka honey total phenols content or antioxidant power are related to the cytotoxicity expressed towards MCF-7 breast cancer cells.

\section{MATERIALS AND METHODS}

\subsection{Manuka Honey Samples and Reagents}

Manuka honey samples rated "Unique Manuka Factor" (UMF) 5+, 10+, 15+, 18+ were purchased from Comvita Ltd (UK). Thyme honey (30\%) was purchased from a Cretan honey producer and was used as control for total phenols assay and antioxidant power assay. The MCF-7 cells were a generous offer of the Cancer Biology Lab, Department of Medicine, University of Crete. RPMI 1640, L-glutamine, sodium bicarbonate, Charcoal stripped-Foetal Bovine Serum (CSFBS), 2,4,6-Tris(2-pyridyl)-s-triazine $(\geq 99.0 \%)$ (TPTZ), gallic acid (97.5-102.5\%), sodium carbonate ( $\geq 99.5 \%$ purity) and Folin- 
Denis reagent were all purchased from Sigma Aldrich Germany. Other laboratory reagents unless otherwise stated were from Sigma Aldrich (UK), Fisher Scientific UK or GE Healthcare (UK).

\subsection{Cell Culture Conditions}

MCF-7 cells were cultured with RPMI640 (+/Lglutamine) supplemented with $10 \%$ CSFBS and $1 \%$ penicillin-streptomycin solution. Confluent cells $(70 \%)$ were treated with trypsin-EDTA $0.25 \%$ solution for detachment.

\subsection{Folin-Ciocalteu Assay for Total Phenols (Total Phenols Content)}

The total phenols content for honey was determined using the Folin-Ciocalteu method described by Singleton et al. [18] with minor modifications $[19,20]$. Briefly, test samples (50 $\mu \mathrm{L}$ ) were added to Eppendorf tubes, with $100 \mu \mathrm{L}$ Folin-Denis reagent and $850 \mu \mathrm{L}$ of sodium carbonate $(3.5 \% \mathrm{w} / \mathrm{v})$ solution. The samples were vortexed briefly and incubated for $20 \mathrm{~min}$ at $37-40^{\circ} \mathrm{C}$. The reacted samples $(800 \mu \mathrm{L})$ were transferred to cuvettes and absorbance was read at $760 \mathrm{~nm}$ using a Shimadzu UV-2700 UV-VIS spectrophotometer. Base-line measurements were carried out using de-ionized water and blank values were deducted from all measurements. Calibrations were produced using gallic acid $3 \mathrm{mM}(0-1000 \mu \mathrm{M})$. Manuka samples (1:10 w/v diluted) were analysed as above and values for total phenols content were expressed as $\mathrm{mg}$ GAE $/ \mathrm{kg}$ of Manuka honey. All analyses were performed in triplicate and repeated on two independent days $(n=6)$ datasets.

\subsection{Determination of Antioxidant Power}

Antioxidant power was measured using the ferric reducing antioxidant power (FRAP) assay as described by Benzie and Strain [21] and adapted for microplate analysis [17]. Briefly, $75 \mu \mathrm{L}$ of test sample were added to Eppendorf tubes followed by $1425 \mu \mathrm{L}$ of FRAP solution. The mixture was vortexed briefly and incubated in $37^{\circ} \mathrm{C}$ water bath for $30 \mathrm{~min}$. Samples $(200 \mu \mathrm{L})$ were transferred to 96-wells microplate and absorbance was read at $593 \mathrm{~nm}$ in the Synergy HT, Bio-TEK microplate reader. Base line calibration was carried out using deionized water. Blank values were deducted from all measurements. The FRAP analysis was calibrated using GA $(0-500 \mu \mathrm{M})$ and Thyme honey from Crete was adopted as a "non-UMF" honey sample. The antioxidant power for samples was expressed as mg gallic acid equivalent antioxidant power (GAEAC) per kilogram of honey. All analyses were performed in triplicate and repeated on two independent days.

\subsection{Cytotoxicity and MTT Assay}

MCF-7 cells were cultured in sterile T-75 flasks at $37{ }^{\circ} \mathrm{C}$ and $3.5 \% \mathrm{CO}_{2}$ atmosphere until $70 \%$ confluence, trypsinized and counted using a Neubauer chamber. Sterile 96-well micro-plates were loaded with $10^{4} /$ well and cells were allowed to attach for 24 hrs. Manuka honey samples were diluted with culture medium $(10 \%, 8.5 \%$, $5 \%, 3.33 \%, 2.5 \%, 2 \%$ and control $(0 \%)$, filter sterilized $(0.2 \mu \mathrm{M})$ and applied to the plated cells. After $24 \mathrm{~h}$ honey and medium were removed from microplates, cells were washed 2-times with cold PBS and $20 \mu \mathrm{L}$ of MTT solution/well was added. Three hours after MTT application DMSO $100 \mu \mathrm{L}$ was added to each well to dissolve the blue formazan crystals and optical density (OD) was measured at $570 \mathrm{~nm}$ two hours later using a Synergy HT, Bio-TEK microplate reader. Optical density (OD) measurements were corrected for "assay" blanks. Results are presented as mean values of eight samples of two different days/datasets.

\subsection{Statistical Analysis}

Correlations between Manuka honey components and UMF strength, MCF-7 percentage cell viability and antioxidant power were calculated using MS-office excel $2010\left(R^{2}\right.$ value). All measurements were carried out in triplicates except the cell viability assay which were done in eight repeats. Mean values and standard deviations (S.D.) are used in Tables and means and standard error of mean (S.E.M.) in figures. Group means were analysed for statistically significant differences using one-way ANOVA followed by Tukey's HSD, or Dunnett'sT3 multiple comparisons post-hoc tests to locate statistically significant differences between pairs of means. Prior to one-way ANOVA data were tested for normality with the Kolmogorov-Smirnov test and for homogeneity of variances with the Levine's test. Where normality was violated replacement of the extreme values ( $>2$ S.D. from the mean or in one case of an outlier very close to 2 S.D. from the mean (total 8 cases out of 256 in MTT assay) with the mean value was effected. Where variables had unequal variances the 
Dunnett's-T3 post-hoc test was used for the separation of means replacing Tukey's test for homogenous variances. Statistical significance was noted with $p$-value less than .05. All analyses were performed using IBM SPSS Statistics v.22 for Windows, Chicago, IL, USA.

\section{RESULTS}

\subsection{Total Phenols and Antioxidant Power of Honey Samples}

According to data from Table 1 Manuka honey samples showed a total phenols content range of 1367-2357 mg GAE /kg honey. A one-way ANOVA test showed the total phenols content for all honeys were significantly different $(P=0.05)$. Thyme honey had a lower mean total phenol content value compared to Manuka honeys. Samples rated UMF $5+$ had almost double the total phenols content than thyme honey, and UMF 18+ had approximately 3.5 folds higher total phenols content. The total phenols content for honey was strongly correlated with UMF rating (thyme was assigned with 0 value in UMF strength) for honey samples $\left(R^{2}=0.9765\right)$. Upon exclusion of thyme honey, the correlation between total phenols content and UMF rating increased $\left(R^{2}=0.9908\right)$.

The antioxidant power of honey samples determined by the FRAP assay is listed in Table 1. A one-way ANOVA test showed that the values for antioxidant power were significantly different for all honeys $(P=0.05)$. The antioxidant power of Manuka honey UMF 5+ was nearly 3-fold higher compared to the value for thyme honey, whilst UMF 18+ Manuka had a 4.4fold higher antioxidant power compared to thyme honey. There was a positive correlation between antioxidant power and UMF ratings for honey $\left(R^{2}=0.9252\right)$, which improved when Manuka samples were regarded alone $\left(R^{2}=0.9978\right)$.
Analysis of linear regression showed that the total phenols content and antioxidant power were highly correlated $\left(R^{2}=0.977\right) \quad(P=0.001)$ and when thyme honey was excluded the change of the regression coefficient was minor $\left(R^{2}=0.980\right)$ $(P=0.01)$.

\subsection{Cell Viability Changes Due to Honey}

Preliminary cytotoxicity tests for honey were performed using treatment durations of $24 \mathrm{hr}$. and $48 \mathrm{hr}$. One-way ANOVA for $24 \mathrm{hr}$ data showed there were statistically significant differences between the honey treatments and medium-only cell culture control (F $(4,35)$ $=32.809, P=.000$, eta squared $=0.789)$ and Dunnett's T3 post-hoc showed that all cytotoxicity values differed statistically significantly from the control $(5+, 10+, 15+P$ $=.001,18+P=.003)$ while between-UMF group comparisons revealed no significant difference for honey at $8.5 \%$ dilution. Using a $48 \mathrm{hr}$. treatment, one-way ANOVA found mean values of Manuka honeys and control groups differed significantly $(F(4,35)=228.831, P=.000$, eta squared=0.963). Post-hoc analysis revealed that all Manuka sample produced a statistically significantly change in cell viability compared with the medium-only control (all $P$-values=.000). There were also statistically significant differences between some comparisons of the means (UMF 5+ vs. UMF $10+(P$-value $=.012)$, UMF $10+$ vs. UMF $18+(P$-value $=.039))$. To allow more rapid screening of samples, the time interval of $24 \mathrm{~h}$ was chosen to further investigate the cytotoxicity of honey towards MCF-7 cells.

Fig. $1 \mathrm{~A}$ shows changes of MCF-7 cell viability following $24 \mathrm{~h}$ treatment with UMF 5+, UMF 10+, UMF 15+ and UMF 18+ Manuka honey. The concentrations of honey in the cell culture medium were $2-10 \% \mathrm{w} / \mathrm{v}$ as shown in Fig. $1 \mathrm{~A}(\mathrm{x}-$ axis). However, each honey has a different total

Table 1. Total phenols content and antioxidant power for Manuka honey (GAEAC mg/kg honey) determined by the Folin Ciocalteu and FRAP assays

\begin{tabular}{lll}
\hline Honey type & $\begin{array}{l}\text { Total phenols content } \\
\text { mg GAE/ kg (n=6) }\end{array}$ & $\begin{array}{l}\text { Antioxidant power } \\
\text { mg GAE / } \mathbf{~ g ~}(\mathbf{n}=6)\end{array}$ \\
\hline Thyme & $692 \pm 65$ & $58.8 \pm 8$ \\
UMF 5+ & $1367 \pm 152$ & $170 \pm 22$ \\
UMF 10+ & $1747 \pm 52$ & $206 \pm 25$ \\
UMF 15+ & $2042 \pm 49$ & $248 \pm 8$ \\
UMF 18+ & $2358 \pm 79$ & $266 \pm 21$ \\
\hline${ }^{*}$ Notes. Values within 2 ${ }^{\text {nd }}$ and $3^{\text {rd }}$ column are significantly different from each other $(P=0.05)$. Assay precision was \\
& $5.9 \%$ (Total phenols) and 9.9\% (Antioxidant power) respectively
\end{tabular}


phenols content (Table 1). Fig. 1B shows the concentration of "active component" in each treatment, presented as total phenols content. Generally, MCF-7 viability declined at honey concentration of $2-10 \%$. The half-maximal inhibitory concentrations $\left(\mathrm{IC}_{50}\right)$, determined using log linear dose-response curves, are shown in Fig. 2. For honey rated UMF $15+$ and $18+$ the IC50 values were virtually identical $(2.1-2.2 \%$ $\mathrm{w} / \mathrm{w}$ honey). The preceding IC50 values were also expressed in terms of the equivalent total phenols content, from which it is evident that UMF $15+$ is probably the most potent honey.

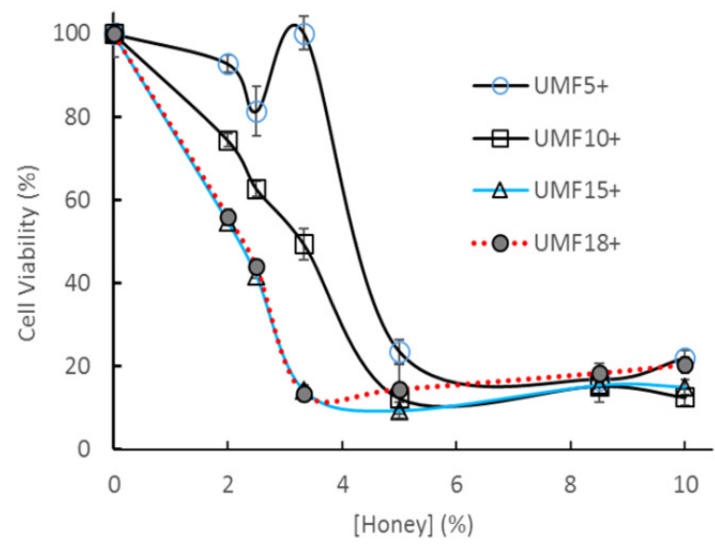

Fig. 1A. Effect of Manuka honey treatment on breast cancer MCF-7 cell viability

Cell were cultured with RPMI 1640 with 10\% Charcoal stripped FBS, 1\%penstrep and assay using the MTT assay. Results are presented as mean values of eight samples of two different days/datasets

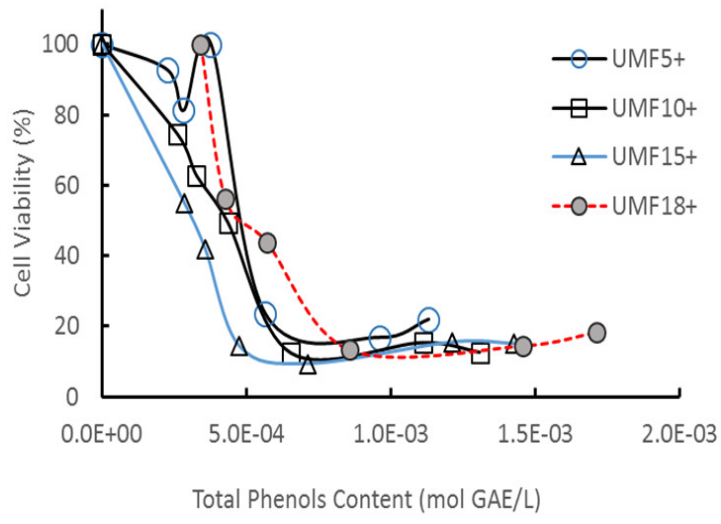

Fig. 1B. Effect of Manuka honey treatment on breast cancer MCF-7 cell viability

Cell were cultured with RPMI 1640 with $10 \%$ Charcoal stripped FBS, 1\%penstrep and assay using the MTT assay. $X$-axis uses the total phenols content to measure of "active components" for each honey treatment. Results are presented as mean values of eight samples of two different days/datasets
In Fig. 1 there was a significant difference in all group comparisons and a post-hoc analysis showed that all cell viability values decreased in comparison with the control except UMF $5+$ at $3.33 \%$. The range of honey concentrations were $2-10 \%$ w/v. For UMF 5+ to UMF 15+ (Fig. 2) there was a high degree of correlation between the IC50 value and UMF rating for honeys. Increasing UMF rating produced declining values for IC50. There was a correlation between IC50 values for honey and the total phenols content $\left(R^{2}=0.9895\right)$ and also between IC50 and the antioxidant (FRAP) measurement $\left(R^{2}=0.9525\right.$; Fig. 3).

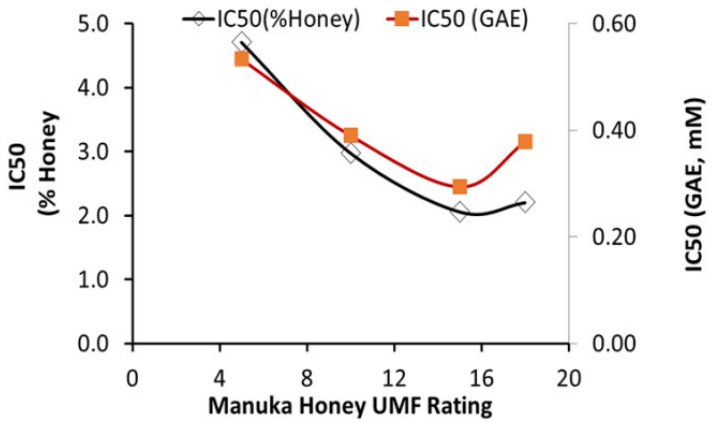

Fig. 2. Effect of Manuka honey UMF rating on the inhibitory concentration (IC50) for breast cancer MCF-7 cells

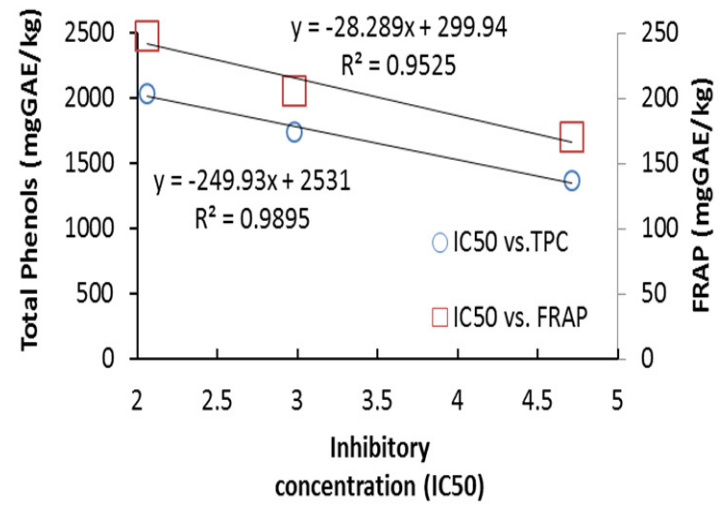

Fig. 3. Relating MC7-7 cell inhibitory concentration (IC50) and honey characteristics

Total phenols content (TPC) and antioxidant power (FRAP) for Manuka honey samples, UMF 5+, UMF $10+$ and UMF 15+

\section{DISCUSSION}

\subsection{Total Phenols Content}

The total phenolic content of Manuka honey is an indicator of its antioxidant power [17]. Variations 
in total phenols content for Manuka honey reflect a variety of agronomic and processing factors [21]. In this investigation there was an increase in the total phenols content for the Manuka honey series UMF $5+<$ UMF $10+<$ UMF $15<$ UMF 18+ (Table 1). The total phenols values reported in this article (Table 1) are similar to reports for Manuka honey originating from the Northland region $(903-2706 \mathrm{mg} / \mathrm{kg}$ ) of New Zealand [22]. The total phenols content for UMF 5+ Manuka honey was 2-fold to 10-fold higher than values reported for other honeys in recent times (Table 2). The total phenol content for honeys described in the literature were typically $500 \mathrm{mg} \mathrm{GAE} / \mathrm{kg}$ or lower [22-38].

A few honeys contain nearly $1000 \mathrm{mg} \mathrm{GAE} / \mathrm{kg}$ including some from Argentina, Brazil, Italy, Burkina Faso and Portugal (Table 2). Most honeys were from the honey bee (Apis mellifera). Interestingly, Kelulut honey from stingless bees (Trigona spp) possessed a higher total phenols content (791-1058 $\mathrm{mg} \mathrm{GAE} / \mathrm{kg}$ ) compared to, values (510.4-589.2 mg GAE/kg) for Gelam, Borneo, Tualang or pineapple honey produced by Apis [23]. Compared to current results some thyme honey samples from Portugal and Morocco had 800-924 mg GAE/kg [33,38] whilst heather honey had 1150-1398 mg GAE/kg [38]. Overall, it seems that Manuka honey belongs to a rare grouping of "super honey" types that contain at least $2000 \mathrm{mg} \mathrm{GAE} / \mathrm{kg}$. A few less well-known honeys from Sudan and Ethiopia were reported to have total phenols content similar or higher than Manuka honey but this data needs collaborating from other investigators (Table 2).

\subsection{Antioxidant Power}

Antioxidant power is one measure of the bioactivity from honey and other food [1,3,4]. Honey is derived from nectar and could potentially contain all classes of plant polyphenols, notably the phenolic acids being either hydroxy-benzoic acids (gallic, protocafeteric, syringic, and vanillic acids) or hydroxycinnamic acids ( $p$-coumaric, ferulic, sinapic and caffeic acids). The flavonoids are also represented, notably flavan-3-ols (catechins, gallocatechin, epicatechin) and flavanols (kaemferol, quercetin, myrecetin) [36]. Specific polyphenols identified from Manuka honey are predominantly phenyllactic acid, gallic acid, methyl-syringate or leptosperin $[1,3,14,22]$. Flavonoids from Manuka honey $(11 \mathrm{mg} / \mathrm{kg}$ ) were predominantly phenyllactic acid, gallic acid, methyl-syringate or leptosperin $[1,3,14,22]$. Flavonoids from Manuka honey $(11 \mathrm{mg} / \mathrm{kg}$ ) were predominantly phenyllactic acid, gallic acid,

Table 2. Total phenols content for select honeys from the literature and this study

\begin{tabular}{|c|c|c|}
\hline Honey & $\begin{array}{l}\text { Total phenols } \\
\text { mg GAE/kg)* }\end{array}$ & Reference \\
\hline Manuka honey & $372-576$ & [17] \\
\hline Manuka honey & $1367-2358$ & This study \\
\hline Manuka honey & $903-2706$ & [22] \\
\hline Malaysian honey (Kelulut honey) & $791-1058$ & [23] \\
\hline Turkish pine honey & 156 & [24] \\
\hline Sourwood, Longan honeys & $564-580$ & [25] \\
\hline Cuban honey (v) & $214-596$ & [26] \\
\hline Saudi Arabia (v) & $111-503$ & [27] \\
\hline Ethiopian honey (v) & $3300-6100$ & [28] \\
\hline Sudanese Honeys (v) & 794- 2327 & [29] \\
\hline Brazilian honey $(v)$ & $685-1085$ & [30] \\
\hline Tualang honey, Malaysia & 840 & [31] \\
\hline Argentina (v) & $400-1930$ & [32] \\
\hline Moroccan, citrus, thyme & $164-924$ & [33] \\
\hline Mexico (v) & $510-1340$ & [34] \\
\hline Italian (v) & $605-2760$ & [35] \\
\hline Obudu, Nigeria & $1060-1300$ & [36] \\
\hline Burkina Faso (v) & $356-1148$ & [37] \\
\hline Portugal (v) & $600-1398$ & [38] \\
\hline
\end{tabular}


methyl-syringate or leptosperin $[1,3,14,22]$. Flavonoids from Manuka honey $(11 \mathrm{mg} / \mathrm{kg}$ ) were thought to contribute to the antioxidant power of honey as measured by the FRAP assay [16].

Manuka honey showed increasing antioxidant power along with UMF rating; the order of decreasing antioxidant power was, UMF $5+<$ UMF 10+<UMF 15+<UMF 18+ (Table 1). The differences in antioxidant power were statistically significant and approximately 4-times higher than values reported when the same samples were analysed earlier [17]. Interestingly, there were no differences in the antioxidant power for UMF 15+ and UMF 18+ Manuka honey samples though values of total phenols content were significantly different. Such results indicate either that polyphenols are not the only compounds contributing to the antioxidant power of Manuka honey samples, or that the FRAP and Folin assays for antioxidant power possess differences in sensitivity. The general correlation between total antioxidant power (FRAP) and total phenols content for honey has been reported previously [26] but other honey constituents (glucose oxidase, catalase, organic acids, amino acids and more) may contribute to the antioxidant power $[1,3,4]$.

\subsection{Anticancer Activity of Manuka Honey with Increasing UMF Rating}

Despite modern scientific breakthroughs and discoveries, cancer mortality rates remain high [11] Chemotherapy, radiotherapy and surgery, all result in undesirable adverse health effects. The interest for alternative treatments has turned the focus to honey's anti-cancer potential. Investigations showed that Tualang honey was cytotoxic towards MCF-7 cells, and protective towards the MCF-10A non-cancerous cell line $[8,9,10]$. In previous studies, the MCF-7 cell was considered a good model for early stage hormone-sensitive cancer [8-11].

The results from the current study agree with those reported from a previous investigation which showed that treating MCF-7 cells with UMF 10+ Manuka honey produced a dosedependent decline in cell viability [11] with the IC50 of $>5 \% \mathrm{w} / \mathrm{v}$ and $4 \% \mathrm{w} / \mathrm{v}$ for $24 \mathrm{hrs}$ or $72 \mathrm{hrs}$ exposure, respectively. By comparison, the IC50 for Manuka honey UMF 10+ was 3\% w/v after 24 hrs in the present study. We found also that IC50 decreased with increasing UMF rating from UMF 5+, UMF 10+, to UMF 15+ (Fig. 2). In addition, results in Fig. 3 showed that MCF-7 inhibition is strongly correlated with the total phenols content and antioxidant power for Manuka samples. In the previous study [11], Manuka honey 10+ was demonstrated to produce a dose-dependent apoptosis in MCF-7 cells.

\section{CONCLUSION}

Manuka honeys rated UMF $5+, 10+, 15+$, and $18+$ exhibit higher apparent total phenols content than most other honey cited in the literature. There is a strong correlation between the total phenols content, antioxidant power, and UMF rating for Manuka honey rated UMF 5+ to UMF $15+$. The current study demonstrated for the first time that Manuka honey cytotoxicity towards breast cancer MCF-7 cells increased with rising UMF $5+$ to UMF $15+$ rating. As a future recommendation further research is needed understand better the effect of Manuka honey on breast cancer cells.

\section{COMPETING INTERESTS}

Authors have declared that no competing interests exist.

\section{REFERENCES}

1. Alvarez-Suarez JM, Gasparrini M, ForbesHernández TY, Mazzoni L, Giampieri F. The composition and biological activity of honey: A focus on Manuka honey. Foods. 2014;3(3):420-32 .

DOI: 10.3390/FOODS3030420.

2. Vandamme L, Heyneman A, Hoeksema H, Verbelen J, Monstrey S. Honey in modern wound care: A systematic review. Burns. 2013;39(8):1514-1525.

DOI: 10.1016/J.BURNS.06.014

PMID: 23896128

3. Jaganathan SK, Mandal M, Antiproliferative effects of honey and of its polyphenols: A review. J Biomed Biotechnology. 2009;2009;1-13.

Available:http://dx.doi.org/10.1155/2009/83 $\underline{0616}$

PMID: 19636435

4. Erejuwa OO, Sulaiman $S A, A B$ Wahab MS. Honey: A novel antioxidant. Molecules. 2012;17(4):4400-4423.

DOI: $10.3390 / \mathrm{MOLECULES19022497}$

PMID: 24566317

5. Ahmed S, Ohtman $\mathrm{NH}$. Honey as a potential natural anticancer agent: $A$ 
review of its mechanisms. Evid Based Complement Alternat Med; 2013.

Available:http://dx.doi.org/10.1155/2013/82 9070

PMID: 24363771

6. Lam YS, Owusu-Apenten R. Enzyme induction and cytotoxicity of phenethyl isothiocyanate and its glutathione conjugate towards breast cancer cells. Pure Appl Chem. Sci. 2013;1(2):63-73.

Available:http://dx.doi.org/10.12988/pacs.2 013.3514

7. Torre LA, Bray F, Siegel RL, Ferlay J, Lortet-Tieulent J, Jemal A. Global cancer statistics, 2012. CA: A Cancer Journal for Clinicians. 2015;65(2):87-108.

DOI: 10.3322/CAAC.21262

8. Yaacob NS, Ismail NF. Comparison of cytotoxicity and genotoxicity of 4hydroxytamoxifen in combination with Tualang honey in MCF-7 and MCF-10A cells. BMC Complement Altern Med. 2014;14(1):1.

Available:http://www.biomedcentral.com/1 472-6882/14/106

PMID: 24646375

9. Fauzi AN, Norazmi MN, Yaacob NS. Tualang honey induces apoptosis and disrupts the mitochondrial membrane potential of human breast and cervical cancer cell lines. Food Chem Toxicol. 2011;49(4):871-878.

DOI: $10.1016 /$ J.FCT.2010.12.010

PMID: 21167897

10. Yaacob NS, Nengsih A, Norazmi MN. Tualang honey promotes apoptotic cell death induced by tamoxifen in breast cancer cell lines. Evid Based Complement Alternat Med; 2013.

Available:http://dx.doi.org/10.1155/2013/98 9841

PMID: 23476711

11. Fernandez-Cabezudo MJ, El-Kharrag R, Torab F, Bashir G, George JA, El-Taji H, et al. Intravenous administration of Manuka honey inhibits tumor growth and improves host survival when used in combination with chemotherapy in a melanoma mouse model. PLoS One. 2013;8(2):e55993.

Available:http://dx.doi.org/10.1371/journal. pone. 0055993

PMID: 23409104

12. Tsiapara AV, Jaakkola $M$, Chinou I, Graikou K, Tolonen T, Virtanen V, et al. Bioactivity of Greek honey extracts on breast cancer (MCF-7), prostate cancer (PC-3) and endometrial cancer (Ishikawa) cells: Profile analysis of extracts. Food Chem. 2009;116(3):702-708.

DOI: 10.1016/J.FOODCHEM.2009.03.024

13. Spilioti $E$, Jaakkola $M$, Tolonen $T$, Lipponen M, Virtanen V, Chinou I, et al. Phenolic acid composition, antiatherogenic and anticancer potential of honeys derived from various regions in Greece. PloS One. 2014;9(4):e94860.

Available:http://dx.doi.org/10.1371/journal. pone. 0094860

PMID: 24752205

14. Kato $Y$, Fujinaka $R$, Ishisaka $A$, Nitta $Y$, Kitamoto N, Takimoto Y. Plausible authentication of Manuka honey and related products by measuring leptosperin with methyl syringate. J Agric Food Chem. 2014;62(27):6400-7.

Available:dx.doi.org/10.1021/jf501475h

PMID: 24941263

15. Kato $\mathrm{Y}$, Umeda $\mathrm{N}$, Maeda $\mathrm{A}$, Matsumoto D, Kitamoto N, Kikuzaki H. Identification of a novel glycoside, leptosin, as a chemical marker of Manuka honey. J Agric Food Chem. 2012;60(13):3418-23.

DOI: $10.1021 / \mathrm{JF} 300068 \mathrm{~W}$

PMID: 22409307.

16. Weston RJ, Mitchell KR, Allen KL. Antibacterial phenolic components of New Zealand Manuka honey. Food Chem. 1999;64(3):295-301 .

DOI: 10.1016/S0308-8146(98)00100-9

17. Henderson T, Nigam PS, Owusu-Apenten RK. A universally calibrated microplate ferric reducing antioxidant power (FRAP) assay for foods and applications to Manuka honey. Food Chem. 2015;174: 119-123.

PMID: 25529660

18. Singleton VL, Orthofer R, LamuelaRaventos RM. Analysis of total phenols and other oxidation substrates and antioxidants by means of Folin-Ciocalteu reagent. Methods in Enzymol. 1999;299: 152-178.

DOI: 10.1016/S0076-6879(99)99017-1

19. Cheung TKN, Singh Nigam P, OwusuApenten R. Antioxidant activity of curcumin and neem (Azadirachta indica) powders: Combination studies with ALA using MCF7 breast cancer cells. J Appl Life Sci Int. 2016;4(3):1-12. DOI: $10.9734 / J A L S I / 2016 / 22273$

20. Yasir M, Sultana B, Nigam P, OwusuApenten R. Antioxidant and genoprotective activity of selected cucurbitaceae seed extracts and LC-ESIMS/MS identification 
of phenolic components. Food Chem. 2016;199:307-313.

PMID: 26775976

21. Benzie IF, Strain JJ. The ferric reducing ability of plasma (FRAP) as a measure of "antioxidant power": The FRAP assay. Anal Biochem. 1996;239(1):70-76.

PMID: 8660627.

22. Stephens JM, Schlothauer RC, Morris BD, Yang D, Fearnley L, Greenwood DR, et al. Phenolic compounds and methylglyoxal in some New Zealand Manuka and kanuka honeys. Food Chem. 2010;120(1):78-86.

DOI: 10.1016/J.FOODCHEM.2009.09.074

23. Kek SP, Chin NL, Yusof YA, Tan SW, Chua LS. Total phenolic contents and colour intensity of Malaysian honeys from the Apis spp. and Trigona spp. bees. Agriculture and Agricultural Science Procedia. 2014;2:150-155.

DOI: 10.1016/J.AASPRO.2014.11.022

24. Özkök A, D'arcy B, Sorkun K. Total phenolic acid and total flavonoid content of Turkish pine honeydew honey. J ApiProd. ApiMedi. Sci. 2010:2;65-71.

DOI: 10.3896/IBRA.4.02.2.01

Available:https://www.researchgate.net/pu blication/250278968

25. Moniruzzaman M, Sulaiman SA, Khalil MI, Gan SH. Evaluation of physicochemical and antioxidant properties of sourwood and other Malaysian honeys: A comparison with Manuka honey. Chem Cent J. 2013:7;138.

DOI: $10.1186 / 1752-153 X-7-138$

PMID: 23938192

26. Alvarez-Suarez JM, Tulipani S, Díaz D, Estevez Y, Romandini S, Giampieri F, Damiani E, Astolfi P, Bompadre S, Battino M. Antioxidant and antimicrobial capacity of several monofloral Cuban honeys and their correlation with color, polyphenol content and other chemical compounds. Food Chem Toxicol. 2010;48(8):24902499.

DOI: 10.1016/J.FCT.2010.06.021 PMID: 20558231

27. Alzahrani HA, Alsabehi $R$, Boukraâ L, Abdellah F, Bellik Y, Bakhotmah BA. Antibacterial and antioxidant potency of floral honeys from different botanical and geographical origins. Molecules. 2012;17(9):10540-10549.

DOI: $10.3390 / M O L E C U L E S 170910540$

PMID: 22948516

28. Sime D, Atlabachew M, Abshiro MR, Zewde T. Total phenols and antioxidant activities of natural honeys and propolis collected from different geographical regions of Ethiopia. Bull. Chem. Soc. Ethiop. 2015:29(2);163-172.

DOI: http://dx.doi.org/10.4314/bcse.v29i2.1

29. Tahir HE, Zou X, Li Z, Zhu Y. Comprehensive evaluation of antioxidant properties and volatile compounds of Sudanese honeys. J Food Biochem. 2015;39(4):349-359.

DOI: $10.1111 / \mathrm{JFBC} .12135$

30. Liberato MDCTC, de Morais SM, Siqueira SMC, de Menezes JESA, Ramos DN, Machado LKA, Magalhaes IL. Phenolic content and antioxidant and antiacetylcholinesterase properties of honeys from different floral origins. J Med Food. 2011;14(6):658-663.

31. Kishore RK, Halim AS, Syazana MN, Sirajudeen KNS. Tualang honey has higher phenolic content and greater radical scavenging activity compared with other honey sources. Nutr Res. 2011;31(4):322325.

DOI: 10.1016/J.NUTRES.2011.03.001 PMID: 21530807

32. Ciappini MC, Stoppani FS. Determination of antioxidant capacity, flavonoids, and total phenolic content in eucalyptus and clover honeys. J Apic Sci. 2014;58(1):103111.

DOI: 10.2478/JAS-2014-0010

33. Aazza S, Lyoussi B, Antunes D, Miguel MG. Physicochemical characterization and antioxidant activity of 17 commercial Moroccan honeys. Int $\mathrm{J}$ Food Sci Nutr. 2014;65(4):449-457.

DOI: $10.3109 / 09637486.2013 .873888$

PMID: 24438231

34. Ruiz-Navajas $Y$, Viuda-Martos $M$, Fernandez-Lopez J, Zaldivar-Cruz JM, Kuri V, Pérez-Álvarez JÁ. Antioxidant activity of artisanal honey from Tabasco, Mexico. Int J Food Prop. 2011;14(2):459470.

DOI: 10.1080/10942910903249480

35. Pichichero E, Canuti L, Canini A. Characterisation of the phenolic and flavonoid fractions and antioxidant power of Italian honeys of different botanical origin. J Sci Food Agri. 2009;89(4):609616.

DOI: $10.1002 / J S F A .3484$

36. Alisi CS, Ojiako OA, Igwe CU, Ujowundu CO, Anugweje K, Okwu GN. Antioxidant content and free radical scavenging activity of honeys of Apis mellifera of 
Obudu cattle ranch. Int $\mathrm{J}$ Biochem Res Rev. 2012;2(4):164.

DOI: $10.9734 / \mathrm{IJBCRR} / 2012 / 1581$

37. Meda A, Lamien CE, Romito M, Millogo J, Nacoulma OG. Determination of the total phenolic, flavonoid and proline contents in Burkina Fasan honey, as well as their radical scavenging activity. Food Chem. 2005;91(3):571-577.

DOI: $10.1016 / J . F O O D C H E M .2004 .10 .006$

38. Alves A, Ramos A, Gonçalves MM, Bernardo M, Mendes B. Antioxidant activity, quality parameters and mineral content of Portuguese monofloral honeys. J Food Comp Anal. 2013;30(2):130-138.

DOI: 10.1016/J.JFCA.2013.02.009

39. Chan CW, Deadman BJ, Manley-Harris M, Wilkins AL, Alber DG, Harry E. Analysis of the flavonoid component of bioactive New Zealand Manuka (Leptospermum scoparium) honey and the isolation, characterization and synthesis of an unusual pyrrole. Food Chem. 2013;141(3): 1772-1781.

DOI: 10.1016/J.FOODCHEM.2013.04.092 PMID: 23870890

(c) 2016 Portokalakis et al.; This is an Open Access article distributed under the terms of the Creative Commons Attribution License (http://creativecommons.org/licenses/by/4.0), which permits unrestricted use, distribution, and reproduction in any medium, provided the original work is properly cited.

Peer-review history:

The peer review history for this paper can be accessed here: http://sciencedomain.org/review-history/15561 